\title{
Airborne Bacterial Populations Above Desert Soils of the McMurdo Dry Valleys, Antarctica
}

\author{
Eric M. Bottos • Anthony C. Woo • Peyman Zawar-Reza • \\ Stephen B. Pointing $\cdot$ Stephen C. Cary
}

Received: 21 April 2013 / Accepted: 17 September 2013 / Published online: 12 October 2013

(C) Springer Science+Business Media New York 2013

\begin{abstract}
Bacteria are assumed to disperse widely via aerosolized transport due to their small size and resilience. The question of microbial endemicity in isolated populations is directly related to the level of airborne exogenous inputs, yet this has proven hard to identify. The ice-free terrestrial ecosystem of Antarctica, a geographically and climatically isolated continent, was used to interrogate microbial bio-aerosols in relation to the surrounding ecology and climate. Highthroughput sequencing of bacterial ribosomal RNA (rRNA) genes was combined with analyses of climate patterns during an austral summer. In general terms, the aerosols were dominated by Firmicutes, whereas surrounding soils supported Actinobacteria-dominated communities. The most abundant
\end{abstract}

Electronic supplementary material The online version of this article (doi:10.1007/s00248-013-0296-y) contains supplementary material, which is available to authorized users.

E. M. Bottos $\cdot$ P. Zawar-Reza $\cdot$ S. B. Pointing $(\bowtie) \cdot$ S. C. Cary $(\bowtie)$ International Centre for Terrestrial Antarctic Research, The

University of Waikato, Private Bag 3105, Hamilton, New Zealand

e-mail: steve.pointing@aut.ac.nz

e-mail: caryc@waikato.ac.nz

E. M. Bottos $\cdot$ S. C. Cary

Department of Biological Sciences, The University of Waikato, Private Bag 3105, Hamilton, New Zealand

A. C. Woo

Sorbonne Paris Cité, Faculté de Médecine, Université Paris

Descartes, Paris Descartes, 24 rue du Faubourg Saint-Jacques,

75014 Paris, France

P. Zawar-Reza

Department of Geography, University of Canterbury,

Private Bag 4800, Christchurch, New Zealand

\section{S. B. Pointing}

Institute for Applied Ecology New Zealand, School of Applied

Sciences, Auckland University of Technology, Private Bag 92006,

Auckland 1142, New Zealand taxa were also common to aerosols from other continents, suggesting that a distinct bio-aerosol community is widely dispersed. No evidence for significant marine input to bioaerosols was found at this maritime valley site, instead local influence was largely from nearby volcanic sources. Back trajectory analysis revealed transport of incoming regional air masses across the Antarctic Plateau, and this is envisaged as a strong selective force. It is postulated that local soil microbial dispersal occurs largely via stochastic mobilization of mineral soil particulates.

\section{Introduction}

The aerosphere is important as a conduit for global transport of bacteria and possibly as an ecological niche in itself. Bacteria can be aerosolized from virtually any surface and typically reach atmospheric concentrations in excess of $1 \times 10^{4}$ cells $/ \mathrm{m}^{3}$ above land and marine surfaces [1-3]. Aerosolized bacteria maintain viability during their atmospheric residence and may exist in the air as spores, vegetative cells, or metabolically active and dividing cells [4]. Bacterial residence times can be several days, facilitating transport over great distances, before their removal from the atmosphere by precipitation or direct deposition onto surfaces [5]. Understanding the extent to which an environment may be impacted by the input of foreign organisms, and identifying the sources of these inputs, is important for understanding ecosystem dynamics and for monitoring ecological change.

Little is known about the contribution of bioaerosol transport to the microbial ecology of isolated systems such as the Antarctic continent. Antarctica is considered to be largely decoupled from systems of global atmospheric transport, due to its geographic isolation and barriers to the mixing of air masses caused by the Antarctic Circumpolar Current [6]. Aerosols over Antarctica are predicted to have longer residence 
times in the atmosphere than those over most temperate environments [5], suggesting that long-range transport of bacteria over the continent is likely. Few analyses of airborne bacteria over Antarctica have been undertaken, with contemporary reports restricted to analyses of microorganisms in the air above Halley V Research Station on the Brunt Ice Shelf [7] and Rothera Point on the Antarctic Peninsula [8]. Aeolian transport is reported to be an important means of local redistribution of organic material and biomass in deserts globally [9] and including the cold polar deserts of Antarctica's ice-free ecosystems [10-14]; however, there have been no descriptions of bacterial diversity in these aerosols.

The McMurdo Dry Valleys in Victoria Land, Antarctica, are the largest ice-free area on the continent $[15,16]$, and deposition of organisms into Dry Valley soils has the potential to profoundly impact ecosystem structure and function [17, 18]. It has recently been suggested that the low bacterial numbers present in Dry Valley soils may enhance the ability of invasive colonists compared to those in soil communities of higher biomass [19]. Many of the same selective pressures faced by organisms in the Dry Valleys including desiccation, high UV radiation, low temperature, and oligotrophic conditions [16] are faced by organisms during atmospheric transport [6]. As such, many bacteria entering Antarctic soils from the atmosphere may be well adapted to survive in their new environment [20]. The likelihood of colonization may be increased by the effects of climate change, as increased temperature and water availability may favor growth of foreign organisms in Antarctic soils [6, 21]. Atmospheric processes may, therefore, have a particularly important role in shaping microbial communities in Dry Valley soils.

In this study, the diversity of airborne bacteria was assessed on the floor and ridge of Miers Valley, a location with extensive landscape-scale ecological research data on the surface ecology [18]. The objective was to set up a baseline dataset for airborne inputs of bacteria and assess how they may influence Dry Valley soils, since soil biodiversity is known to vary with elevation in this system [16, 22].

\section{Materials and Methods}

\section{Air Sampling}

Aerosol samples were collected by filtration onto $0.2-\mu \mathrm{m}$ pore-size polycarbonate filters by impaction using solarpowered pumps (SKC, 224-PCXR8, Eighty Four, PA, USA) mounted $1 \mathrm{~m}$ above the ground in each location. This height was chosen since the majority of local dust mobilization has been shown to occur at this near-ground interface (Cary et al., unpublished data). Filters inserted into cassette apparatus but not exposed to air flow were used as controls. All filters and cassettes were UV-sterilized and rinsed with $70 \%$ alcohol before use. Sampling apparatus was deployed $1 \mathrm{~m}$ above the ground surrounded with a $2 \mathrm{~mm}$ gauze baffle on the Miers Valley Floor $\left(78^{\circ} 05^{\prime} .78 \mathrm{~S}, 163^{\circ} 47^{\prime} .25 \mathrm{E}\right.$, approx. $\left.270 \mathrm{~m}\right)$ and Miers Valley Ridge $\left(78^{\circ} 06^{\prime} .83 \mathrm{~S}, 163^{\circ} 47^{\prime} .18 \mathrm{E}\right.$, approx. $550 \mathrm{~m}$ ). Samples were collected from a continuous filtration period December 11, 2009 to January 25, 2010 (55 days), with an estimated sample volume of 75,000 1 for each location. Filters were stored at $-20{ }^{\circ} \mathrm{C}$ during transit from Antarctica and until processed.

DNA Extraction, Amplification, and Sequencing

Total DNA was extracted directly from the filters using the DNeasy Plant Mini Kit (Qiagen, CA, USA), after first washing with kit lysis buffer for $10 \mathrm{~min}$. The remaining steps of the extraction were carried out according to the manufacturers instructions. Recovered DNA was quantified using NanoDrop ${ }^{\mathrm{TM}}$ (Thermo Scientific, Waltham, MA, USA).

For each sample, PCR targeting the V5-V7 region of the 16S rRNA gene was completed in duplicate. Each $30 \mu \mathrm{l}$ reaction contained $1 \times$ PrimeSTAR buffer, $0.2 \mathrm{mM}$ dNTPs, $0.75 \mathrm{U}$ PrimeSTAR HS DNA Polymerase (Takara Holdings, Kyoto, Japan), $0.4 \mu \mathrm{M}$ of primers Tx9 (5'-GGATTAGAWACCCBG GTAGTC-3') and 1391R (5'-GACGGGCRGTGWGTRCA-3') [23], and $5 \mu \mathrm{l}$ of template DNA. Thermal cycling conditions consisted of $94{ }^{\circ} \mathrm{C}$ for $3 \mathrm{~min} ; 30$ cycles of $94{ }^{\circ} \mathrm{C}$ for $20 \mathrm{~s}, 52^{\circ} \mathrm{C}$ for $20 \mathrm{~s}$, and $72{ }^{\circ} \mathrm{C}$ for $45 \mathrm{~s}$; and $72{ }^{\circ} \mathrm{C}$ for $3 \mathrm{~min}$. All thermal cycling was completed on a Bio-Rad DNA Engine Peltier Thermal Cycler 200 (Bio-Rad, Hercules, CA, USA). Duplicate reactions were pooled, and amplicons were size-selected from agarose gels using a MO BIO Gel Extraction Kit (MO BIO Laboratories, Carlsbad, CA, USA). Gel extracted products were cleaned using an Agencourt AMPure XP system (Beckman Coulter, Brea, CA, USA) and quantified using a Qubit dsDNA HS Assay Kit and Qubit 2.0 Fluorometer (Life Technologies, Carlsbad, CA, USA).

To prepare the amplicons for sequencing, a second round of PCR was completed in triplicate. PCR reactions were prepared as outlined above, but using $10 \mathrm{ng}$ of purified amplicon as the template and primers MIDX-Tx9F (5'CCATCTCATCCCTGCGTGTCTCCGACTCAG-MIDGGATTAGAWACCCBGGTAGTC-3') and BacB_1391R (5'-CCTATCCCCTGTGTGCCTTGGCAGTCTCAGGACGGGCRGTGWGTRCA-3'), adapted for one-way reads with unique MID identifiers for each sample. Thermal cycling conditions were as outlined above, but reduced to 13 cycles. Triplicate products were pooled, gel-extracted, cleaned, and quantified as outlined above, before quantification of amplifiable molecules using a KAPA Library Quantification Kit for Roche 454 Titanium/Universal (Kapa Biosystems, Woburn, MA, USA) on a Corbett Rotor-Gene 6000 realtime thermal cycler (Life Technologies). Amplicons were 
sequenced using the GS Junior Titanium emPCR Kit (Lib-L), the GS Junior Titanium Sequencing Kit, PicoTitrePlate Kit, and GS Junior System (Roche 454 Life Sciences, Branford, CT, USA) at The University of Waikato DNA Sequencing Facility.

\section{Analysis of Sequencing Data}

Raw sequence data was analyzed using AmpliconNoise v1.25 with default parameters [24]. Chimeric sequences were removed using Perseus [24]. Sequences were processed in Mothur v1.24.1 [25]. Pairwise distances were calculated using ESPRIT [26] and sequences grouped at $97 \%$ identity into operational taxonomic units $\left(\mathrm{OTU}_{0.03}\right)$ using average neighbour clustering. Unique sequences had to be observed a minimum of three times in order for them to be retained for further analyses. Sequences were assigned to taxonomic groups using the Classifier function of the Ribosomal Database Project (RDP) Release 10 [27] with a confidence threshold of $80 \%$, and sequences were compared to those in the NCBI database using the BLASTn algorithm [28].

Phylogenetic analyses were carried out in MEGA v5.05 [29]. Sequences were aligned over 266 homologous positions of the 16S rRNA gene using Clustal W. A neighbour-joining tree was constructed based on the alignment using default parameters, except rates among sites were adjusted to be gamma distributed, rather than uniform. The phylogenetic tree was tested based on bootstrap analysis with 1,000 replications.

In addition to the NCBI database, Miers Valley aerosol sequences were compared to those from previously published datasets using the BLASTn algorithm. The first dataset included 31 bacterial clone sequences reported in air samples over Halley Station, West Antarctica [7] (GenBank accession numbers FN431986-FN432029). The second dataset included all bacterial sequences observed in a Miers Valley soil sample that was used as a control site in a recent study [17]. The third dataset included 1,320 sequences from ice-free areas of Antarctica [16]: Anchorage Island, Coal Nunatak, Fossil Bluff, and Mars Oasis [30] (GenBank accession numbers EF219488-EF220012; EF220190-220371; 220735220903), Miers Valley and Bratina Island [31] (GenBank accession numbers DQ062859-DQ062918), Luther Vale [32] (GenBank accession numbers EF464767-EF465090), Ross Island [33] (GenBank accession numbers AY571818AY571845), and Marble Point and Wright Valley [34] (GenBank accession numbers DQ365987-DQ366018). Pyrosequencing data was also screened for possible user contamination, using commonly accepted indicators of human microflora and pathogens as previously described [35-39]. The pyrosequencing datasets generated in this study are deposited in the European Nucleotide Archive, under accession number ERP002362 (http://www.ebi.ac.uk/ena/data/view/ ERP002362).
Meteorological Data and Back Trajectory Analyses

Back trajectories were generated with the internet-based version of HYSPLIT, to establish the source regions of air masses advecting over Miers Valley during the sampling period [40]. Seven-day back trajectories released at $500 \mathrm{~m}$ above ground level (AGL) were obtained using the GDAS database for every other day; to allow for adequate vertical mixing in the atmosphere during transport, the isentropic option for calculating the back trajectories was selected. Although the resolution of GDAS is not adequate enough to show transport within the Dry Valleys system, it should still elucidate the long-range transport source regions accurately.

\section{Results}

From the Miers Floor sample, a total of 22,271 reads matching the barcode were obtained, and 12,113 of these (574 unique sequences) were retained following quality checks. From the Miers Ridge sample, 22,101 reads matching the barcode were obtained, and 11,467 of these (600 unique sequences) were retained. Following removal of sequences that occurred less than three times between the two air sample libraries, a total of 202 OTUs $_{0.03}$ were retained for analyses (Supplementary Table 1, Supplementary Figure 1). Control filters yielded no recoverable DNA thus confirming the fidelity of our aerosol sampling setup. The majority of the total sequences observed grouped into $\mathrm{OTUs}_{0.03}$ common to both libraries. The 73 OTUs $_{0.03}$ shared between the two libraries accounted for $95.3 \%$ and $93.6 \%$ of the sequences observed in the Miers Floor and Miers Ridge samples, respectively (Supplementary Table 2). A total of 64 OTUs $_{0.03}$ were observed only in the Miers Floor sample, and 65 OTUs $_{0.03}$ were observed only in the Miers Ridge sample, accounting for $4.7 \%$ and $6.4 \%$ of the sequences in these libraries, respectively.

We recorded only ten OTUs 0.03 (five in both samples, one only in the Miers Floor sample, and four only in the Miers Ridge sample) in the entire dataset for both locations that displayed 91-99\% sequence similarity to human skin (Dermacoccus, Flavobacteria, Lactobacillus, Micrococcus, Propionibacteria, Staphylococcus) or fecal (Escherichia) microflora; no pathogenic taxa were detected in the libraries. These taxa indicative of human contamination comprised less than $1 \%$ of the sequences in the two libraries, and since most were phylogenetically also very closely related to common soil bacteria, we conclude negligible human contamination to our sequence dataset.

In both samples, sequences grouping to the Firmicutes dominated libraries, and sequences grouping to the Actinobacteria, Bacteroidetes, and Cyanobacteria constituted minor proportions of the libraries (Fig. 1). The highest diversity was observed in the Proteobacteria with a total of 73 
Fig. 1 Phylum level distributions of sequences observed in the Miers ridge $(R)$ and Miers valley floor $(V)$ bacterial aerosol libraries (this study), plus surrounding soils $(S)$ [17] Phylum assignments were made using the Classifier function of the Ribosomal Database Project (RDP) Release 10 [26] with a confidence threshold of $80 \%$

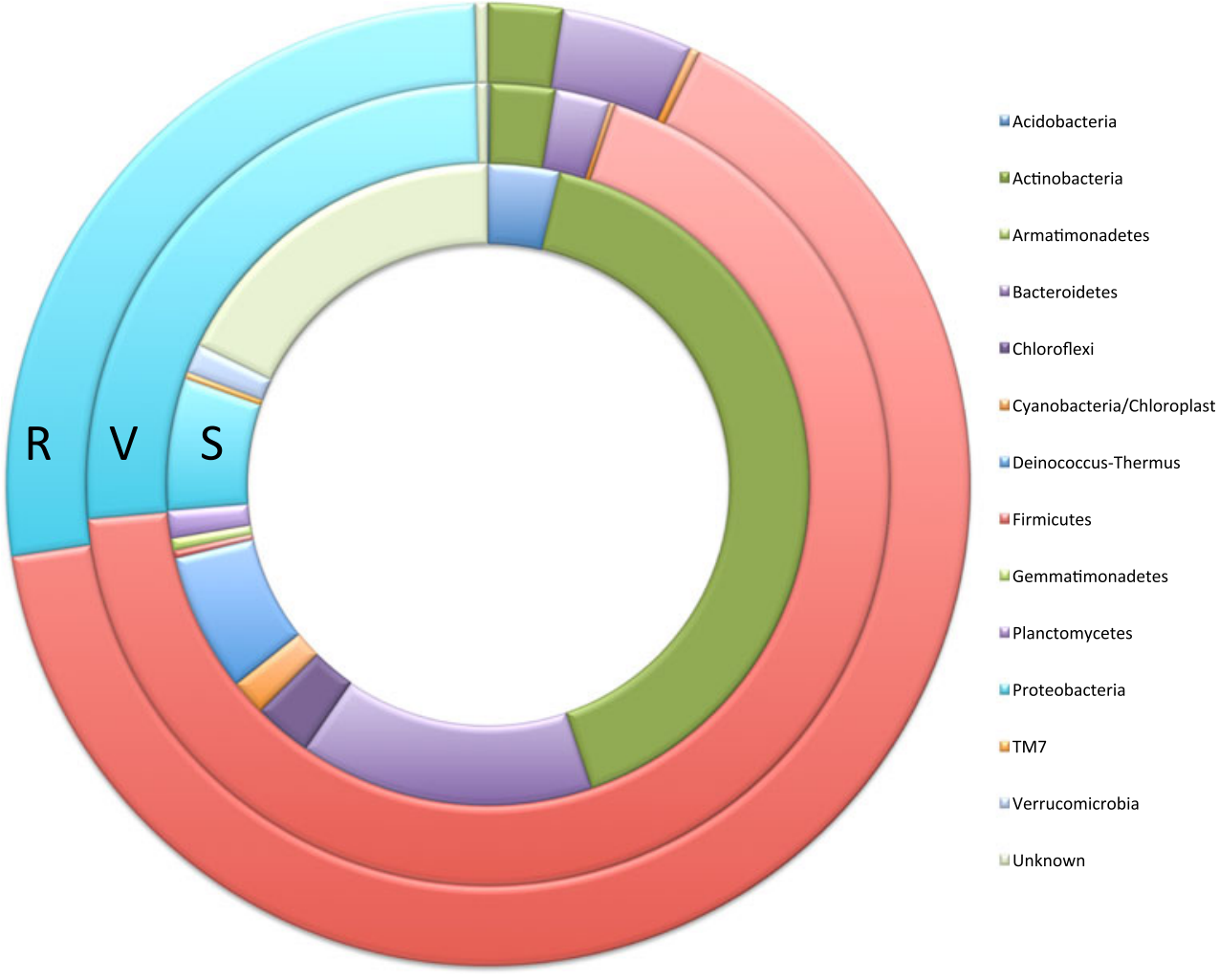

$\mathrm{OTUs}_{0.03}$ found to group to the phylum, representing the classes Alpha-, Beta-, and Gamma-proteobacteria. The Firmicutes were represented by $56 \mathrm{OTUs}_{0.03}$, which predominantly grouped to the classes Bacilli and Clostridia. The Actinobacteria were represented by $21 \mathrm{OTUs}_{0.03}$, the Bacteroidetes by $13 \mathrm{OTUs}_{0.03}$, and the Cyanobacteria by 4 $\mathrm{OTUs}_{0.03}$. A single $\mathrm{OTU}_{0.03}$ grouping to the Acidobacteria was observed in low abundance in the Miers Floor library, but could not be confidently grouped beyond the phylum level. Thirty four OTUs $\mathrm{S}_{0.03}$ could not be confidently grouped to a phylum.

The phylogenetic compositions of the libraries were influenced heavily by five OTUs ${ }_{0.03}$, which dominated both samples (Table 1). These sequences were found to cluster well with cultured representatives of the taxonomic groups to which they were assigned by RDP Classifier (Fig. 2). Many of the dominant sequences were found to group closely with known thermophilic genera. Sequences of $\mathrm{OTU}_{0.03} 159$ grouped within the Firmicutes to the genus Thermaerobacter and shared $99 \%$ sequence identity with its closest BLAST match, Thermaerobacter subterraneus, an isolate from a hydrothermal system [41]. Sequences of OTU ${ }_{0.03} 238$ were found to share $100 \%$ sequence identity with isolate Geobacillus tepidamans, which has been recovered from highly disparate thermal environments, including geothermal systems and food processing facilities [42]. The most abundant phylotype found to group to the Proteobacteria, $\mathrm{OTU}_{0.03}$
9, also had a closest cultured match to the thermophilic bacteria Lysobacter thermophiles YIM $7785^{\mathrm{T}}$, which was isolated from a geothermal soil in China [43]; however, this sequence has also been reported in numerous culture independent analyses from diverse environments including air from a high elevation site in Colorado, USA [44] and glacial ice in the Antarctic Dry Valleys [45].

The two dominant sequences grouping to the family Paenibacillaceae, OTUs ${ }_{0.03} 166$ and 176 (Table 1), had closest BLAST matches of $99 \%$ sequence identity to an uncultured

Table 1 Taxonomic assignments of the most abundant $\mathrm{OTUs}_{0.03}$ observed in the Miers Floor and Miers Ridge bacterial aerosol libraries

\begin{tabular}{lllll}
\hline OTU & $\begin{array}{l}\text { Miers Floor } \\
(\%)\end{array}$ & $\begin{array}{l}\text { Miers Ridge } \\
(\%)\end{array}$ & RDP assignment & $\begin{array}{l}\text { Confidence } \\
(\%)\end{array}$ \\
\hline 9 & 15.7 & 15.1 & Xanthomonadaceae $^{\mathrm{f}}$ & 100 \\
159 & 24.6 & 6.7 & Thermaerobacter $^{\mathrm{g}}$ & 100 \\
166 & 7.3 & 11.3 & Paenibacillaceae $^{\mathrm{f}}$ & $81-100$ \\
176 & 23.5 & 14.3 & Paenibacillaceae $^{\mathrm{f}}$ & $87-100$ \\
238 & 8.2 & 24.4 & Bacillaceae $^{\mathrm{f}}$ & 100 \\
\hline
\end{tabular}

Assignments were made using the Classifier function of the Ribosomal Database Project (RDP) Release 10 [26] with a confidence threshold of $80 \%$

${ }^{\mathrm{f}}$ Sequences grouped to family

${ }^{\mathrm{g}}$ Sequences grouped to genus 


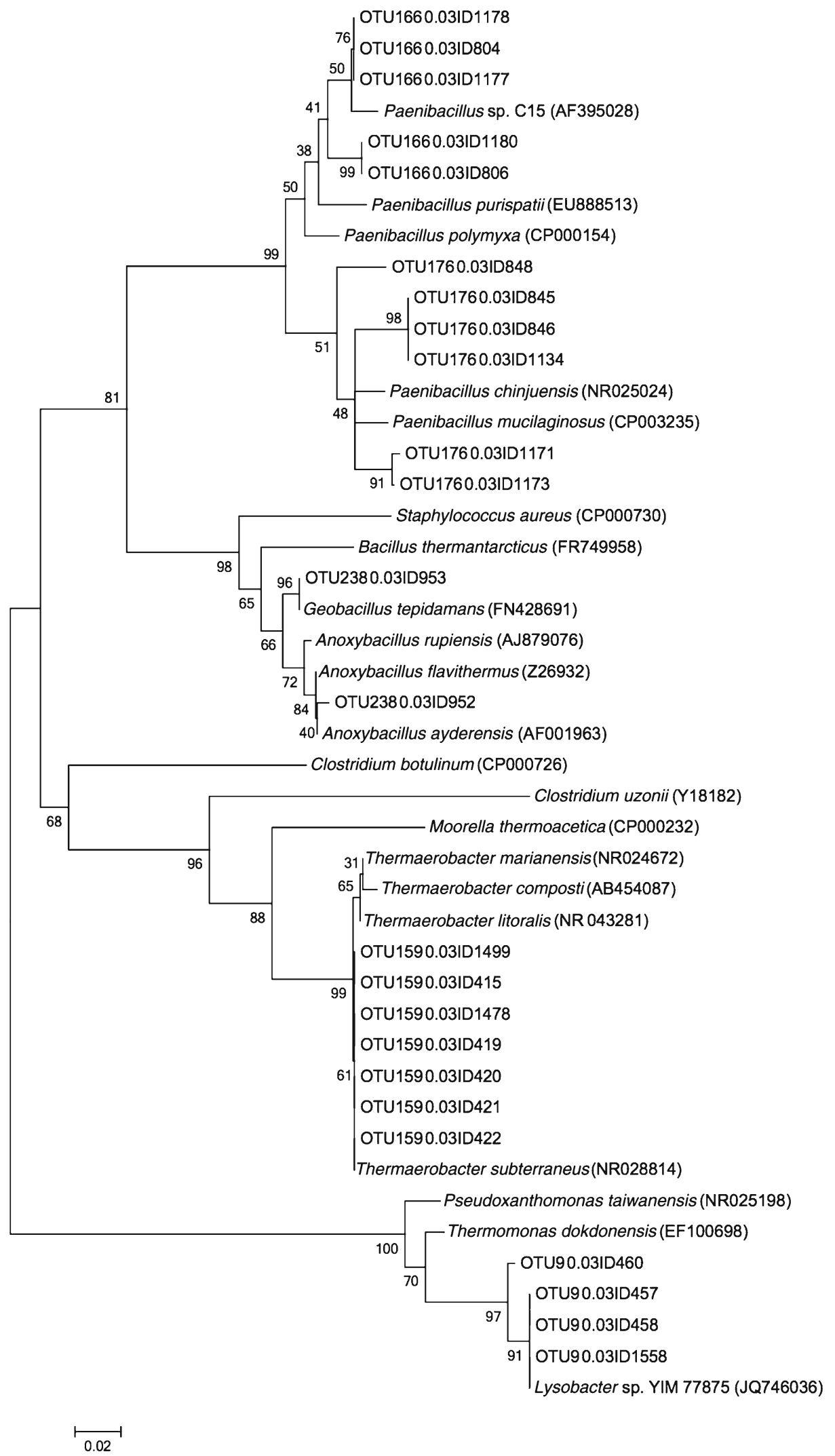

Fig. 2 Neighbour-joining tree illustrating the phylogenetic relationships of sequences from the five most abundant OTUs o. $_{03}$ observed in the Miers Floor and Miers Ridge bacterial aerosol libraries. The tree is based on a Clustal W alignment of $16 \mathrm{~S}$ rRNA gene sequences over
266 homologous positions. Bootstrap support is shown at each node as a percentage, based on 1,000 resampled datasets. The scale indicates the number of substitutions per nucleotide position 
bacteria associated with an insect host [46] and to an uncultured bacteria associated with a mud volcano in the Mediterranean [47], respectively. Their closest cultured matches were with $98 \%$ sequence identity to isolate Paenibacillus sp. C15, from Lake Vostok accretion ice and with $98 \%$ sequence identity to Paenibacillus chinjuensis, an isolate from a soil in Korea.

Few sequences in the Miers Valley aerosol libraries were also present in the Halley Station aerosols, Miers Valley soil, or Antarctic ice-free areas databases. Sequences from 5 OTUs $_{0.03}$ observed in the Miers aerosol libraries matched 7 of the 31 clones reported in the Halley Station aerosols with $>97 \% 16 \mathrm{~S}$ rRNA gene sequence identity, and these OTUs $\mathrm{S}_{0.03}$ accounted for $3.2 \%$ and $0.5 \%$ of the Miers Floor and Miers Ridge samples, respectively. Sequences from $13 \mathrm{OTUs}_{0.03}$ observed in the aerosol libraries matched sequences in the Miers soil library with $>97 \% 16 \mathrm{~S}$ rRNA gene sequence identity, but these sequences made up $<3 \%$ of either aerosol library. Sequences from $34 \mathrm{OTUs}_{0.03}$ were found to be present in either the Miers soil library or soils from other ice-free areas in Antarctica, and these OTUs ${ }_{0.03}$ accounted for $6.6 \%$ and $5.3 \%$ of the Miers Floor and Miers Ridge samples, respectively.

Seven-day back trajectories indicated that the air masses influencing the sample sites came predominantly from the plateau, with few events immediately influenced by the marine environment (Fig. 3). An Automatic Weather Station (AWS) installed in the valley floor shows that the typical surface flow was easterly (up-valley) for December and January (data is not available between December 12 to January 18 due to equipment failure). As is typical for this season, strong katabatic storms did not occur and wind speeds diurnally oscillated between 7 to $0.5 \mathrm{~m} / \mathrm{s}$ in response to the solar insolation.

\section{Discussion}

The soils and rocks of Antarctica's Dry Valleys support unique microbial communities that are able to tolerate the harsh environmental conditions [16]. This study demonstrated that the aerosol immediately above this edaphic niche supports a bacterial diversity that includes a very low frequency of OTUs related to local soil colonists and instead is dominated by OTUs that suggest that the extensive local active volcanology, together with strong selective pressure from regional transport above the Antarctic plateau, may be the dominant factors determining airborne bacterial dispersal.

The lack of correlation between aerosolized 'communities' and local edaphic communities in our study is an enigma. It is recognized that dust transport is a major mechanism for microbial dispersal in deserts worldwide [9], and studies of microbial signatures in Antarctic soils indicate this may also be the case in the Dry Valleys, at least on a local scale [11]. Yet during a large part of the Austral summer, our evidence suggests that local edaphic bacteria form a negligible part of the dust-free airborne biota. We propose that this may be due to microbes associated with mineral soil (dust) particles that were frozen solid to the surface and/or too heavy to have been collected by our pumping apparatus, and therefore dustassociated microbes were under-represented in our study. We may therefore have detected only bacteria being transported as very fine particulates. Soil microbial communities also exhibit relatively low biomass $[11,48]$ and may be dispersed during occasional stochastic events rather than in a continuous manner, and this may contribute to relatively stochastic demography between such desert locations $[49,50]$.

At the phylum level, the signatures observed in the Miers Valley aerosols were largely similar to those reported in aerosols over other terrestrial environments. Studies of aerosols from Texas [35], Colorado [51], Hong Kong [39], and the Canadian High Arctic [52] report similar representation of major phyla. This evidence supports suggestions that bacteria from these groups may have characteristics that enhance their ability to be aerosolized and survive harsh conditions in the atmosphere [51]. That the same bacteria that are important globally in aerosols are important in Antarctic aerosols suggests there may be common controls to bacteria during high atmospheric transport, and this may be independent of geographic location.

At the $\mathrm{OTU}_{0.03}$ level, there was also evidence that Miers bio-aerosols were similar to those outside Antarctica. The most abundant $\mathrm{OTU}_{0.03}$ grouping to the Proteobacteria was also observed in air from a high elevation site in Colorado, USA [44]. Several sequences of lower abundance in the Miers library were also recorded from aerosols over tropical terrestrial and marine environments [39], thus suggesting that some taxa are globally distributed in the atmosphere.

Aerosols over Miers Valley showed much higher diversity than those reported from other parts of the continent. This result is at least partially attributable to the use of high-throughput sequencing in the current study (thus resolution power in our study was several orders of magnitude greater than in earlier studies), but may also in part reflect landscape differences between the two study sites influencing aerosol compositions. Pearce and colleagues [7] proposed that the 31 clones and 12 partial sequences reported in aerosols over Halley Station represented a baseline of biodiversity for aerosols over the continent, due to limited impact from local biological sources. Our observation of seven of the taxa described in the Halley Station libraries among the 202 OTUs seen in aerosols over Miers Valley is in agreement with this concept and may indicate that there are some bacterial taxa that can be predictably observed in aerosols over the entire continent. The difference in bacterial assemblages observed between the two studies demonstrates a degree of temporal and/or spatial variation in aerosol compositions over Antarctica. 
Fig. 3 Hysplit [39] back trajectories showing the origin of air masses influencing the sample site over the sampling period (yellow highlight)

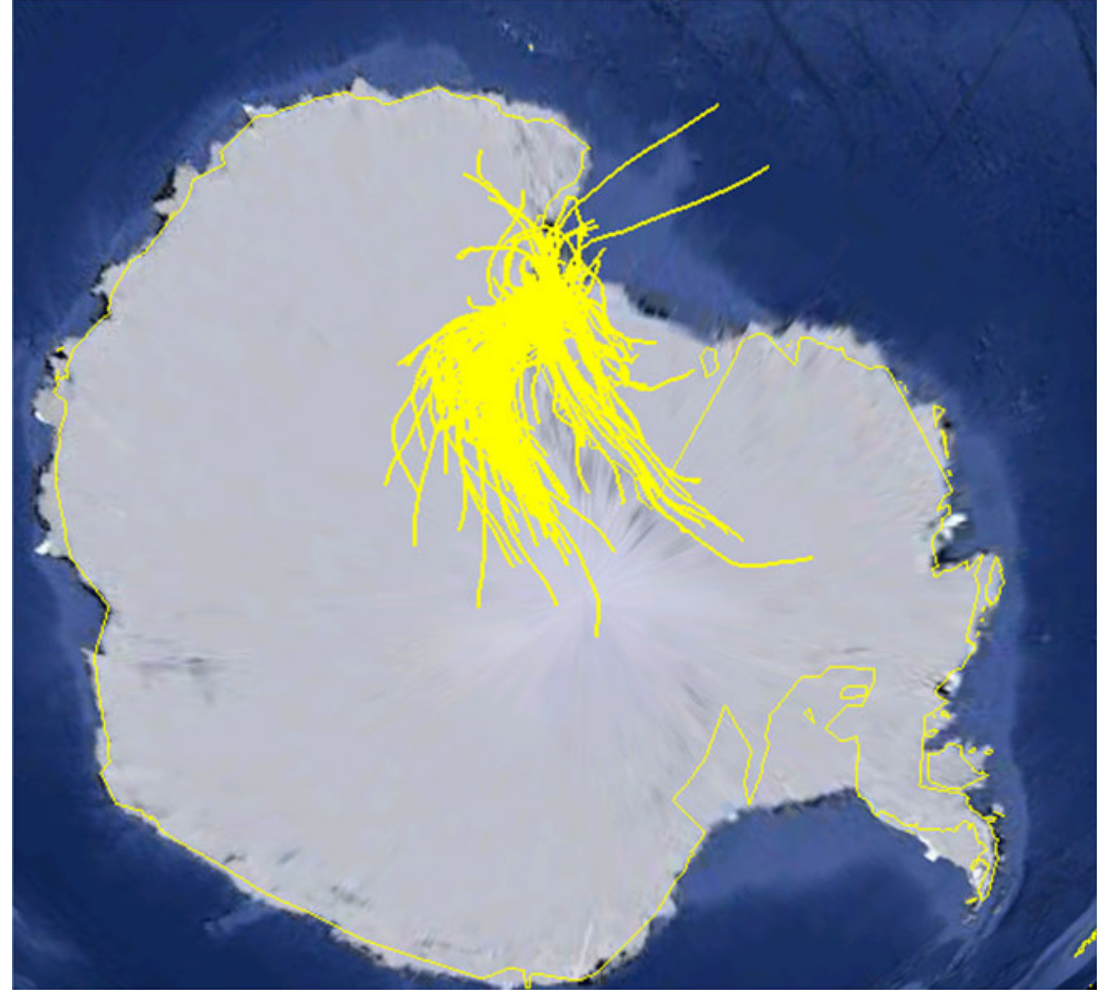

There was little evidence that local soils, lakes, glaciers, or the Ross Sea had a marked influence on bacterial aerosol compositions. The air sample libraries were found to be highly dissimilar to the reference soil sample library at both the phylum and $\mathrm{OTU}_{0.03}$ level. In stark contrast to the Miers Valley aerosols, work by Tiao and colleagues [17] indicated that the Miers soils were dominated by sequences grouping to Actinobacteria (37.3\%) and Bacteroidetes (12.6\%), while those grouping to Firmicutes $(<1 \%)$ and Proteobacteria (Alphaproteobacteria $1.6 \%$, Betaproteobacteria $<1 \%$, and Gammaproteobacteria $<1 \%$ ) made up small proportions of the library. All of the phyla observed in the air samples were observed in the soils, but many in the soil samples including the Deinococcus-Thermus, Chloroflexi, Planctomycetes, and Verrucomicrobia were not detected in either air sample. Sequences from only $13 \mathrm{OTUs}_{0.03}$ in the Miers aerosol libraries were also observed in the soil library, and none of the dominant signatures in the aerosol libraries were represented. This indicates strong selective pressure in Dry Valleys soils towards community assembly that greatly enhances abundance of 'rare' phylotypes from the incoming airborne (rather than dust-borne) inoculum. We further postulate that dispersal is a largely regional process and occurs via stochastic dust storm events, whilst a more passive low-level but continuous aerosol input from air movements harbours a largely non-invasive aerosolized microbial input. It is also possible that the level of biomass in Dry Valley soils surrounding the sample sites was too low to have a detectable influence on the composition of bacterial aerosols, although cyanobacteria that form high biomass microbial mats around lakes and hypoliths in quartzbearing soils were undetected and so this appears unlikely.

Of the bacteria detected, none were confidently considered to be of marine origin from the nearby Ross Sea. This is consistent with the analysis of back trajectories for wind, which showed weather arriving predominantly from the interior of the continent. Pearce and colleagues [7] also noted limited marine influence on aerosols at Halley Station in peninsular Antarctica, with only three bacterial sequences of marine origin and no discernable variation in bacterial aerosol compositions when the distance to open water was reduced from 400 to $15 \mathrm{~km}$ during seasonal break up of the sea-ice. Hughes and colleagues [8] also reported that only three of the sequences detected in aerosols over Rothera Point were of marine origin, despite close proximity to the open ocean and the marine influence on much of the air arriving at the station. Based on the climatic trends over the sampling period, it is, perhaps, not surprising that little marine influence was observed in the Miers Valley aerosols.

The substantial number of sequences in both libraries that appear to be from thermophilic bacteria was unexpected, but may be explained by influences from the many areas of geothermal activity in the Ross Sea region. Potential sources of thermophilic organisms include Mount Erebus $100 \mathrm{~km}$ northeast of the Miers Valley, and Mount Melbourne and Mount Rittman approximately 400 and $500 \mathrm{~km}$ north of the Miers Valley, respectively. These sites host diverse and 
abundant thermophilic microbial communities [53-55]. Bacteria may be aerosolized from these sites in steam that rises from the fumaroles, similar to the mechanism of dispersal described in other geothermal systems [56, 57]. Considering the close proximity of the Dry Valleys to these ecosystems, relative to other significant stocks of microbial biomass, it is reasonable to suggest that these volcanoes, particularly Mt. Erebus, may have an important influence on the composition of bacterial aerosols in the region.

We postulate that at least some aerosolized bacteria arrived via inter-continental dispersal. Indeed, Vincent [58] cites numerous lines of evidence for the frequent transfer of biological material to Antarctica by atmospheric processes. Bacteria have been shown to survive long-distance transport in desert dust blown between Africa and the Caribbean [59]. Many of the bacteria observed in the Miers aerosols may be long lived in the atmosphere, particularly the spore-forming taxa grouping to the phylum Firmicutes. The high proportion of Firmicutes observed in these libraries could be the result of selection for spore-forming bacteria during long-range transport, as the Paenibacillus, Geobacillus/Anoxybacillus, and Thermaerobacter found to dominate the Miers aerosols can all be considered to be cosmopolitan in distribution $[42,60]$ and may be highly mobile as spores.

We conclude, however, that the majority of the bacteria observed in the aerosols originated in Antarctica, rather than from off the continent. Antarctica has been hypothesized to have one of the lowest rates of microbial exchange with other continents and marine environments, with an estimated $90 \%$ of the aerosols deposited in Antarctic environments predicted to have originated from on the continent [5]. The dust that arrives in Antarctica is predicted to be predominantly from Australia and Patagonia, with the Ross Sea region most heavily influenced by the Australian fraction [61], and there is little reason to expect these aerosols to be dominated by thermophiles. That all of the dominant members are thermophilic suggests that there is a common nearby source, as a mechanism for the selection in favour of thermophilic bacteria in the cold atmosphere is difficult to conceive.

Acknowledgments The authors are extremely grateful to Antarctica New Zealand for logistics and field support in Antarctica.

\section{References}

1. Bauer H, Kasper-Giebl A, Löflund M, Giebl H, Hitzenberger R, Zibuschka F, Puxbaum H (2002) The contribution of bacteria and fungal spores to the organic carbon content of cloud water, precipitation and aerosols. Atmos Res 64:109-119

2. Burrows S, Elbert W, Lawrence MG, Pöschl U (2009) Bacteria in the global atmosphere: Part 1. Review and synthesis of literature data for different ecosystems. Atmos Chem Phys 9:9263-9280
3. Cho BC, Hwang CY (2011) Prokaryotic abundance and 16S rRNA gene sequences detected in marine aerosols on the East Sea (Korea). FEMS Microbiol Ecol 76:327-341

4. Sattler B, Puxbaum H, Psenner R (2001) Bacterial growth in supercooled cloud droplets. Geophys Res Lett 28:239-242

5. Burrows S, Butler T, Jöckel P, Tost H, Kerkweg A, Pöschl U, Lawrence MG (2009) Bacteria in the global atmosphere: Part 2. Modeling of emissions and transport between different ecosystems. Atmos Chem Phys 9:9281-9297

6. Pearce DA, Bridge PD, Hughes KA, Sattler B, Psenner R, Russell NJ (2009) Microorganisms in the atmosphere over Antarctica. FEMS Microbiol Ecol 69:143-157

7. Pearce DA, Hughes KA, Lachlan-Cope T, Harangozo SA, Jones AE (2010) Biodiversity of air-borne microorganisms at Halley Station, Antarctica. Extremophiles 14:145-159

8. Hughes KA, McCartney HA, Lachlan-Cope TA, Pearce DA (2004) A preliminary study of airborne microbial biodiversity over Peninsular Antarctica. Cell Mol Biol (Noisy-le-grand) 50:537-542

9. Pointing SB, Belnap J (2012) Microbial colonization and controls in dryland systems. Nat Rev Microbiol 10:551-562

10. Hopkins DW, Sparrow AD, Novis PM, Gregorich EG, Elberling B, Greenfield LG (2006) Controls on the distribution of productivity and organic resources in Antarctic Dry Valley soils. Proc Biol Sci 273: 2687-2695

11. Hopkins DW, Sparrow AD, Gregorich EG, Elberling B, Novis P, Fraser F, Scrimgeour C, Dennis PG, Meier-Augenstein W, Greenfield LG (2009) Isotopic evidence for the provenance and turnover of organic carbon by soil microorganisms in the Antarctic dry valleys. Environ Microbiol 11:597-608

12. Priscu JC, Fritsen CH, Adams EE, Giovannoni SJ, Paerl HW, McKay CP, Doran PT, Gordon DA, Lanoil BD, Pinckney JL (1998) Perennial Antarctic lake ice: an oasis for life in a polar desert. Science 280: 2095-2098

13. Nkem JN, Wall DH, Virginia RA, Barrett JE, Broos EJ, Porazinska DL, Adams BJ (2006) Wind dispersal of soil invertebrates in the McMurdo Dry Valleys, Antarctica. Polar Biol 29:346-352

14. Michaud L, Caruso C, Mangano S, Interdonato F, Bruni V, Lo Giudice A (2012) Predominance of Flavobacterium, Pseudomonas, and Polaromonas within the prokaryotic community of freshwater shallow lakes in the northern Victoria Land, East Antarctica. FEMS Microbiol Ecol 82:391-404

15. Levy J (2013) How big are the McMurdo Dry Valleys? Estimating ice-free area using Landsat image data. Antarctic Sci 25:119-120

16. Cary SC, McDonald IR, Barrett JE, Cowan DA (2010) On the rocks: the microbiology of Antarctic Dry Valley soils. Nat Rev Microbiol 8: 129-138

17. Tiao G, Lee CK, McDonald IR, Cowan DA, Cary SC (2012) Rapid microbial response to the presence of an ancient relic in the Antarctic Dry Valleys. Nat Commun 3:660

18. Lee CK, Barbier BA, Bottos EM, McDonald IR, Cary SC (2012) The inter-valley soil comparative survey: the ecology of Dry Valley edaphic microbial communities. ISME J 6:1046-1057

19. Cowan DA, Chown SL, Convey P, Tuffin M, Hughes K, Pointing S, Vincent WF (2011) Non-indigenous microorganisms in the Antarctic: assessing the risks. Trends Microbiol 19:540-548

20. Chan Y, van Nostrand JD, Zhou J, Pointing SB, Farrell RL (2013) Functional ecology of an Antarctic Dry Valley. Proc Natl Acad Sci U S A 110:8890-8895

21. Hughes KA, Ott S, Bölter M, Convey P (2006) Colonisation processes. In: Bergstrom DM, Convey P, Huiskes AHL (eds) Trends in Antarctic Terrestrial and Limnetic Ecosystems. Springer Netherlands, Dordrecht, pp 35-54

22. Cowan DA, Pointing SB, Stevens MI, Craig Cary S, Stomeo F, Tuffin IM (2011) Distribution and abiotic influences on hypolithic microbial communities in an Antarctic Dry Valley. Polar Biol 34: 307-311 
23. Ashby MN, Rine J, Mongodin EF, Nelson KE, Dimster-Denk D (2007) Serial analysis of rRNA genes and the unexpected dominance of rare members of microbial communities. Appl Environ Microbiol 73:4532-4542

24. Quince C, Lanzen A, Davenport RJ, Turnbaugh PJ (2011) Removing noise from pyrosequenced amplicons. BMC Bioinformatics 12:38

25. Schloss PD, Westcott SL, Ryabin T et al (2009) Introducing mothur: open-source, platform-independent, community-supported software for describing and comparing microbial communities. Appl Environ Microbiol 75:7537-7541

26. Sun Y, Cai Y, Liu L, Yu F, Farrell ML, McKendree W, Farmerie W (2009) ESPRIT: estimating species richness using large collections of 16S rRNA pyrosequences. Nucl Acids Res 37:e76

27. Wang Q, Garrity GM, Tiedje JM, Cole JR (2007) Naive Bayesian classifier for rapid assignment of rRNA sequences into the new bacterial taxonomy. Appl Environ Microbiol 73:5261-5267

28. Altschul SF, Gish W, Miller W, Myers EW, Lipman DJ (1990) Basic local alignment search tool. J Mol Biol 215:403-410

29. Tamura K, Peterson D, Peterson N, Stecher G, Nei M, Kumar S (2011) MEGA5: molecular evolutionary genetics analysis using maximum likelihood, evolutionary distance, and maximum parsimony methods. Mol Biol Evol 28:2731-2739

30. Yergeau E, Newsham KK, Pearce DA, Kowalchuk GA (2007) Patterns of bacterial diversity across a range of Antarctic terrestrial habitats. Environ Microbiol 9:2670-2682

31. Smith JJ, Tow LA, Stafford W, Cary C, Cowan DA (2006) Bacterial diversity in three different Antarctic cold desert mineral soils. Microb Ecol 51:413-421

32. Niederberger TD, McDonald IR, Hacker AL, Soo RM, Barrett JE, Wall DH, Cary SC (2008) Microbial community composition in soils of Northern Victoria Land, Antarctica. Environ Microbiol 10:17131724

33. Saul DJ, Aislabie JM, Brown CE, Harris L, Foght JM (2005) Hydrocarbon contamination changes the bacterial diversity of soil from around Scott Base, Antarctica. FEMS Microbiol Ecol 53:141-155

34. Aislabie JM, Chhour K-L, Saul DJ, Miyauchi S, Ayton J, Paetzold RF, Balks MR (2006) Dominant bacteria in soils of Marble Point and Wright Valley, Victoria Land, Antarctica. Soil Biol Biochem 38: 3041-3056

35. Brodie EL, DeSantis TZ, Moberg Parker JP, Zubietta IX, Piceno YM, Andersen GL (2007) Urban aerosols harbor diverse and dynamic bacterial populations. Proc Natl Acad Sci U S A 104:299-304

36. Kembel SW, Jones E, Kline J, Northcutt D, Stenson J, Womack AM, Bohannan BJ, Brown GZ, Green JL (2012) Architectural design influences the diversity and structure of the built environment microbiome. ISME J 6:1469-1479

37. Luna LK, Panning M, Grywna K, Pfefferle S, Drosten C (2007) Spectrum of viruses and atypical bacteria in intercontinental air travelers with symptoms of acute respiratory infection. J Infect Dis 195:675-679

38. Tringe SG, Zhang T, Liu X et al (2008) The airborne metagenome in an indoor urban environment. PLoS ONE 3:e1862

39. Woo AC, Brar MS, Chan Y, Lau MCY, Leung FCC, Scott JA, Vrijmoed LLP, Zawar-Reza P, Pointing SB (2013) Temporal variation in airborne microbial populations and microbiallyderived allergens in a tropical urban landscape. Atmos Environ 74:291-300

40. Draxler RR, Hess GD (1998) An overview of the HYSPLIT 4 modelling system for trajectories, dispersion, and deposition. Aust Meteor Mag 47:295-308

41. Spanevello MD, Yamamoto H, Patel BKC (2002) Thermaerobacter subterraneus sp. nov., a novel aerobic bacterium from the Great Artesian Basin of Australia, and emendation of the genus Thermaerobacter. Int J Syst Evol Microbiol 52:795-800

42. Schäffer C, Franck WL, Scheberl A, Kosma P, McDermott TR, Messner P (2004) Classification of isolates from locations in Austria and Yellowstone National Park as Geobacillus tepidamans sp. nov. Int J Syst Evol Microbiol 54:2361-2368

43. Wei D-Q, Yu T-T, Yao J-C, Zhou E-M, Song Z-Q, Yin Y-R, Ming H, Tang S-K, Li W-J (2012) Lysobacter thermophilus sp. nov., isolated from a geothermal soil sample in Tengchong, south-west China. Antonie van Leeuwenhoek 102:643-651

44. Bowers RM, Lauber CL, Wiedinmyer C, Hamady M, Hallar AG, Fall R, Knight R, Fierer N (2009) Characterization of airborne microbial communities at a high-elevation site and their potential to act as atmospheric ice nuclei. Appl Environ Microbiol 75:5121-5130

45. Bidle KD, Lee S, Marchant DR, Falkowski PG (2007) Fossil genes and microbes in the oldest ice on Earth. Proc Natl Acad Sci U S A 104:13455-13460

46. Brucker RM, Bordenstein SR (2012) The roles of host evolutionary relationships (genus: Nasonia) and development in structuring microbial communities. Evolution 66:349-362

47. Heijs SK, Laverman AM, Forney LJ, Hardoim PR, van Elsas JD (2008) Comparison of deep-sea sediment microbial communities in the Eastern Mediterranean. FEMS Microbiol Ecol 64:362-377

48. Pointing SB, Chan Y, Lacap DC, Lau MCY, Jurgens JA, Farrell RL (2009) Highly specialized microbial diversity in hyper-arid polar desert. Proc Natl Acad Sci U S A 106:19964-19969

49. Bahl J, Lau MCY, Smith GJD et al (2011) Ancient origins determine global biogeography of hot and cold desert cyanobacteria. Nat Commun 2:163

50. Caruso T, Chan Y, Lacap DC, Lau MCY, McKay CP, Pointing SB (2011) Stochastic and deterministic processes interact in the assembly of desert microbial communities on a global scale. ISME J 5:1406-1413

51. Fierer N, Liu Z, Rodríguez-Hernández M, Knight R, Henn M, Hernandez MT (2008) Short-term temporal variability in airborne bacterial and fungal populations. Appl Environ Microbiol 74:200-207

52. Harding T, Jungblut AD, Lovejoy C, Vincent WF (2011) Microbes in high Arctic snow and implications for the cold biosphere. Appl Environ Microbiol 77:3234-3243

53. Soo RM, Wood SA, Grzymski JJ, McDonald IR, Cary SC (2009) Microbial biodiversity of thermophilic communities in hot mineral soils of Tramway Ridge, Mount Erebus, Antarctica. Environ Microbiol 11:715-728

54. Bargagli R, Broady PA, Walton DWH (1996) Preliminary investigation of the thermal biosystem of Mount Rittmann fumaroles (northern Victoria Land, Antarctica). Antarctic Sci 8:121-126

55. Logan NA, Lebbe L, Hoste B, Goris J, Forsyth G, Heyndrickx M, Murray BL, Syme N, Wynn-Williams DD, De Vos P (2000) Aerobic endospore-forming bacteria from geothermal environments in northern Victoria Land, Antarctica, and Candlemas Island, South Sandwich archipelago, with the proposal of Bacillus fumarioli sp. nov. Int J Syst Evol Microbiol 50:1741-1753

56. Bonheyo GT, Frias-Lopez J, Fouke BW (2005) A test for airborne dispersal of thermophilic bacteria from hot springs. In: Inskeep WP, McDermott TR (eds) Geothermal Biology and Geochemistry in Yellowstone National Park. Montana State University Publications, Bozeman, pp 327-340

57. Ellis DG, Bizzoco RW, Kelley ST (2008) Halophilic Archaea determined from geothermal steam vent aerosols. Environ Microbiol 10: $1582-1590$

58. Vincent WF (2000) Evolutionary origins of Antarctic microbiota: invasion, selection and endemism. Antarctic Sci 12:374-385

59. Kellogg CA, Griffin DW, Garrison VH, Peak KK, Royall N, Smith RR, Shinn EA (2004) Characterization of aerosolized bacteria and fungi from desert dust events in Mali, West Africa. Aerobiologia 20:99-110

60. Yabe S, Kato A, Hazaka M, Yokota A (2009) Thermaerobacter composti sp. nov., a novel extremely thermophilic bacterium isolated from compost. J Gen Appl Microbiol 55:323-328

61. Li F, Ginoux P, Ramaswamy V (2008) Distribution, transport, and deposition of mineral dust in the Southern Ocean and Antarctica: Contribution of major sources. J Geophys Res 113:D10207 